\title{
The diet of Eurasian Tree Sparrow Passer montanus nestlings in relation to agri-environment scheme habitats
}

by McHugh,N.H., Prior, M., Leather, S.R. and Holland, J.M.

Copyright, Publisher and Additional Information: Author's accepted manuscript published by Taylor and Francis in Bird Study.

\section{A note on versions:}

The version presented here may differ from the published version or, version of record, if you wish to cite this item you are advised to consult the publisher's version.

Harper Adams

University 
1 The diet of Eurasian Tree Sparrow Passer montanus 2 nestlings in relation to agri-environment scheme habitats

4 Niamh M. McHugh ${ }^{1,4}$, Matt Prior $^{2}$, Simon R. Leather ${ }^{3}$, John M. Holland ${ }^{4}$

5 1. Silwood Park Campus, Imperial College London, Buckhurst Road, Ascot, Berkshire, $6 \quad$ SL5 7PY, UK

7 2. Wiltshire Ornithology Society, 4 Beddae Close, Bradford on Avon, BA15 1UP, UK

3. Crop and Environment Sciences, Harper Adams University, Newport, TF10 8NB, UK

4. Game and Wildlife Conservation Trust, Fordingbridge, Hampshire, SP6 1EF, UK

10

11 Corresponding author:

12 Niamh M. McHugh

13 Email: niamh.mc-hugh10@imperial.ac.uk

14 Phone: +441425651056 
15 Capsule It has been suggested by some authors that the UK agri-environment 'wild bird seed' option negatively impacts Tree Sparrow populations in the UK. Here we provide evidence for a change in nestling diet with increasing wild bird seed coverage and propose a possible mechanism for its negative impact on population trends.

The intensification of agriculture has been implicated as a major factor driving the population decline of farmland birds including the Eurasian Tree Sparrow Passer montanus (hereafter Tree Sparrow) in the United Kingdom (UK; Newton 2004). The Tree Sparrow is a mixed diet species; adults require grain and wild plant seed but nestlings are dependent on invertebrate food resources (Holland et al. 2006). Across Europe, farmland invertebrate populations have decreased due to the increased use of pesticides and herbicides (Stoate et al. 2001). Additionally ${ }_{2}$ the proportion of non-cropped areas available to foraging birds have declined (Stoate et al. 2001). Insect taxa are an essential protein source for farmland bird chicks and reduced invertebrate availability may have detrimental consequences on chick survival, affecting their development and flight feather growth (Borg \& Toft 1999, 2000; Southwood et al. 2002) as well as increasing their risk of hypothermia (Potts 2012). When invertebrates are scarce, farmland birds such as Yellowhammer Emberiza citrinella and Cirl Bunting Emberiza cirlus, are known to supplement nestling diet with seed despite its lower protein and energy content to the equivalent weight of invertebrates (Evans et al. 1997; Douglas et al. 2009).

Agri-environment schemes (AES) comprise a suite of prescriptive management strategies that are employed across Europe to, in part, alleviate biodiversity problems related to agricultural intensification (Kleijn \& Sutherland 2003) The English AES, Environmental Stewardship (ES) contained offered several habitat options that should boost Tree Sparrow chick food availability, including ungrazed grass margins and field corners (Vickery et al. 
2002). In contrast, the value of an ES wild bird seed (WBS) option to breeding Tree Sparrow is currently the subject of debate. WBS is designed as a seed-rich food resource for granivorous birds in winter. Holland et al. (2014) showed that at a plot scale this habitat can also provide high levels of chick food for farmland birds during the breeding season, however this calculation included some invertebrate groups that are uncommon in the diet of Tree Sparrow nestlings e.g. Nuroptera and Formicidae (Field et al. 2008). More recently, Bright et al. (2015) has-reported regional scale declines in breeding densities of Tree Sparrow and the area of WBS on mixed farmland. High concentrations of feeding birds leading to increased predation pressure was the suggested cause of this negative effect (Baker et al. 2012), but here we investigate an alternative mechanism for declining populations by relating nestling diet to the prevalence of this habitat.

The aim of this study was to define the dietary niche of Tree Sparrow nestlings and to investigate if the presence of key invertebrate food items or seed in their diet is influenced by the coverage of grass AES habitat (an aggregate group consisting of a number of structurallysimilar grassy habitats such as grass margins and wildflower margins) or annual WBS ES habitats on arable farmland. The following predictions were tested: (1) The presence of key invertebrate food groups were expected to positively correlate with Grass AES coverage and (2) The presence of seed in faecal sacs were expected to positively correlate with WBS cover.

From mid-June to July 2013, nestling diet on 17 Tree Sparrow colony sites (from 9

61 farms) on the Marlborough and Pewsey Downs was assessed (Figure 1). This area has been designated as high priority for Entry Level Stewardship farmland bird conservation by Natural England. Sites were mixed farmland with habitat types available to colonies including permanent pasture (18 883.461 $\left.\pm 3116.256 \mathrm{~m}^{2}\right)$, arable crops (92 
$654.1503 \pm 3028.375 \mathrm{~m}^{2}$; barley, Triticum, wheat, Hordeum and oilseed rape, Brassica napus

spp.) along with small patches of woodland $\left(1682.962 \pm 358.403 \mathrm{~m}^{2}\right)$. Nestling diet was assessed from faecal samples $(\mathrm{n}=83)$ collected from 41 broods where nestlings were between 7 and 10 days old. This represents a period when chicks develop rapidly and energy is being invested in feather growth (Ramsay \& Houston 2003). Samples were stored in tubes and frozen before being processed for identification. Faecal analysis was used to define Tree Sparrow diet following the method described by Moreby (1988). The presence of seed and cereal husks in samples was also recorded and grouped under the category "seed". We analysed how nestling diet relates to grass ES (mean $\pm \mathrm{SE}=1898.533 \pm 308.344$ $\mathrm{m}^{2} ;$ range $\left.=0-18222 \mathrm{~m}^{2}\right)$ and WBS $\left(\right.$ mean $\pm \mathrm{SE}=1452.027 \pm 239.452 \mathrm{~m}^{2} ;$ range $=0-5026.536$ $\left.\mathrm{m}^{2}\right)$ habitat coverage within the average foraging range of an adult Tree Sparrow $(200 \mathrm{~m}$; Summer-Smith, 1995). Using Generalized Linear Mixed-effects Models (GLMMs) with the packages lme4 and language R, in R version 3.0.3 (Bates et al. 2015; R Core Development Team, 2014) the response variables were: 1 . Presence or absence of taxon groups comprising $>5 \%$ nestling diet (see later); 2 . The presence/absence of seed in faecal sacs. Faecal analysis may underrepresent species identified by fragile structures that are often completely digested by the animal and over-report those identified by more robust remains (Gooch et al. 2015). Because of this, data on the percentage occurrence of key food items were not analysed as no corrections factor specific to Tree Sparrow exist that account for the possible undercounting of soft bodied food items.

Farms, colonies within farms and a brood identification number were included in models as nested random effects. GLMMs were constructed with a binomial error distribution and logit link function. The package LMERConvenienceFunctions was used to check model assumptions (Tremblay 2015). 
All Tree Sparrow nestling faecal samples contained invertebrate remains, comprising

Araneae $(7.45 \pm 0.90 \%$ of all invertebrate food items), Carabidae $(16.41 \pm 1.54 \%)$, other adult Coleoptera (Cantharidae, Chrysomelidae, Coccinellidae, Curculionidae, Elateridae, Staphylinidea, Scarabidae; $15.32 \pm 1.69 \%)$, Coleoptera larvae $(14.19 \pm 2.41 \%)$, Diptera $(22.06 \pm 1.60 \%)$, Lepidoptera Larvae $(6.29 \pm 1.46 \%)$, Tipulidae $(11.27 \pm 0.50 \%)$ and other invertebrates (Acarina, Aphididae, Dermaptera, Gastropoda, Homoptera, Hymenoptera, Opiliones, unidentified Coleoptera; $7.01 \pm 0.98 \%$ ) and seed was present in $51 \%$ of faecal samples $(n=83)$ and was fed to $78 \%$ of broods $(n=41)$. Faecal sacs were more likely to contain seed where WBS coverage was high, but had no significant relationship with grass ES (Table 1). No correlations between the invertebrate taxa investigated and grass ES or WBS coverage were found (Table 1). It is important to consider that because this study involved multiple statistical tests ${ }_{2}$ it is possible that some of the observed effects are type I errors.

Past studies of Tree Sparrow diet have highlighted Lepidoptera as a major dietary component (approximately 28\%; Holland et al. 2006). In this study, however, Lepidoptera larvae accounted for only $6.29 \%$ of their diet. This finding may reflect national declines in Lepidoptera abundance, a theory that has been proposed by Field et al. (2008), who found Lepidoptera only represented 7\% of Tree Sparrow chick food items. There is evidence that nationally Lepidoptera have declined over the same period as threatened farmland bird species (Benton et al. 2002; Conrad et al. 2006; Fox et al. 2011).

Although the invertebrate taxa consumed by Tree Sparrow chicks were unaffected by grass ES coverage the presence of grain in their diet positively correlated with WBS coverage. Invertebrate food provides a better source of protein and supplies particular amino acids that facilitate growth; these are often absent or only present in very low proportions in plant food (Potts 2012). This is known to depress nestling body condition in other farmland 
bird species e.g. Yellowhammer (Douglas et al. 2012) and can impact their future survival and fitness as a consequence (Wright et al. 1998, Lindstrom 1999).

WBS is primarily a winter habitat and was represented by short $(0.35 \mathrm{~m} \pm 0.22 \mathrm{~m})$ sparse vegetation at the time of sampling (pers obs). Invertebrate abundance increases with the height and structural diversity of a habitat (Eyre \& Leifert 2011) and it is therefore unlikely that invertebrate food resources were abundant in this habitat. WBS is generally planted in April or May meaning that during the peak breeding season (May-July) the habitat is not sufficiently developed to provide seeds for foraging adults. Since spring sown WBS appears to provide little in the way of food during the breeding season, Tree Sparrows may be resorting to feeding in cropped areas instead ${ }_{2}$ and as they support few insects (Holland et al. 2012), this is responsible for the higher prevalence of grain in nestling diets. This does not necessarily negate the benefits of WBS as a winter food resource (Stoate et al. 2004), but it is important that it does not come at the cost of brood rearing resources that are vital to maintain productivity. WBS may be improved as a summer foraging habitat by sowing in the autumn instead of spring, this practice is already carried out by some farmers and results in a more mature spring/summer crop which should positively impactresult in increased invertebrate populations. Planting two year in place of annual WBS strips may also benefit breeding Tree Sparrow as two-year strips are much better at providing invertebrates in their second year due to increased weed cover (J. Holland et al. unpubl. data).

The increased presence of grain in the diet of nestlings with WBS coverage may offer an explanation for declining Tree Sparrow population growth on mixed farmland, but it assumes this relationship reflects a decision by parents to supplement nestling diet with grain at the cost of invertebrates. Further research is needed in order to verify that increased seed intake results in reduced insect mass within the diet but this is currently limited as no correction factors for Tree Sparrow faecal analysis were available to account for potentially 
139 undercounting soft bodied prey. Correction factors may also be important in investigation the

140 relationship between the abundance of key dietary items and grass AES as the

141 presence/absence data used in our analysis may have been too course to detect such a

142 relationship.

143

\section{Acknowledgements}

145 This project was funded by a BBSRC case studentship with the Game and Wildlife

146 Conservation Trust (GWCT), additional funding was provided by Natural England. We are

147 grateful to the landowners who granted us access to their land over the course of the project.

148 Thanks to CJ Heward for comments on an early draft of the manuscript. 


\section{References}

Baker, D.J., Freeman, S.N., Grice, P. V. \& Siriwardena, G.M. 2012. Landscape-scale responses of birds to agri-environment management: a test of the English Environmental Stewardship scheme. J. Appl.Ecol 49: 871-882.

Bates, D., Maechler, M., Bolker, B., Walker, S., Christensen, R.H.B., Singmann, H. \& Dai, B. 2015. Package "lme4". URL http://cran.r-project.org/web/packages/lme4/lme4.pdf

Benton, T.G., Bryant, D.M., Cole, L. \& Crick, H.Q. 2002. Linking agricultural practice to insect and bird populations: a historical study over three decades. J. Appl.Ecol 39: 673-687.

Borg, C. \& Toft, S. 1999. Value of the aphid Rhopalosiphum padi as food for grey partridge Perdix perdix chicks. Wildl. Biol 5: 55-58.

Borg, C. \& Toft, S. 2000. Importance of insect prey quality for grey partridge chicks Perdix perdix: a self-selection experiment. J. Appl.Ecol 37: 557-563.

Bright, J.A., Moris, A.J., Field, R.H., Cooke, A.I., Grive, P.V., Walker, L.K., Fern, J. \& Peach, W.J. 2015. Higher-tier agri-environmnet scheme enhances breeding densities of some priority farmland birds in England. Agric. Ecosyst. Environ 203: 69-79.

Conrad, K.F., Warren, M.S., Fox, R, Parson, M.S \& Woiwod, I.P. 2006. Rapid declines of common, widespread British moths provide evidence of an insect biodiversity crisis. Biol. Conserv 132: 279-291.

Douglas, D.J.T., Moreby, S.J. \& Benton, T.G. 2012. Provisioning with cereal grain depresses the body condition of insectivorous Yellowhammer Emberiza citrinella nestlings. Bird Study 59: 105-109.

Evans, A.D., Smith, K.W., Buckingham, D.L. \& Evans, J. 1997. Seasonal variation in breeding prefprmance and nestling diet of Cirl Bunting Emberiza cirlus in England. Bird Study 44: 66-79.

Eyre, M.D. \& Leifert, C. 2011. Crop and field boundary influences on the activity of a wide range of beneficial invertebrate groups on a split conventional/organic farm in northern England. Bull. Entomol. Res 101: 135-44.

Field, R.H., Anderson, G.Q.A. \& Gruar, D.J. 2008. Land-use correlates of breeding performance and diet in Tree Sparrows Passer montanus : Capsule Chick diet varies seasonally and between wet and dry habitats, and there is little evidence for a link between habitat type and productivity. Bird Study 55: 280-289.

Fox, R., Randle, Z., Hill, L., Anders, S., Wiffer, L. \& Parsons, M.S. 2011. Moths count: recording moths for conservation in the UK. J. Insect Conserv 15: 55-68.

Gooch, S., Ashbrook, K., \& Székely, T. 2015. Using dietary analysis and habitat selection to inform conservation management of reintroduced Great Bustards in an agricultural landscale. Bird Study 62: 289-302 


\begin{abstract}
Holland, J.M., Hutchison, M.A.S., Smith, B. \& Aebischer, N.J. 2006. A review of invertebrates and seed-bearing plants as food for farmland birds in Europe. Ann. Appl. Biol 148: $49-71$.
\end{abstract}

Holland J.M., Smith B.M., Birkett T.C. \& Southway S. 2012. Farmland bird invertebrate food provision in arable crops. Ann. Appl. Biol 160: 66-75.

Holland, J.M., Storkey, J., Lutman, P.J.W., Birkett, T.C., Simper, J. \& Aebischer, N.J. 2014. Utilisation of agri-environment scheme habitats to enhance invertebrate ecosystem service providers Agric. Ecosyst. Environ 183: 103-109.

Kleijn, D. \& Sutherland, W.J. 2003. How effective are European agri-environment schemes in conserving and promoting biodiversity? J. Appl.Ecol 40: 947-969.

Lindstrom, J. 1999. Early development and fitness in birds and mammals. TREE 14: 343348 .

Moreby, S.J. 1988. An aid to the identification of arthropod fragments in the faeces of gamebird chicks (Galliformes). Ibis 130: 519-526.

Newton, I. 2004. The recent declines of farmland bird populations in Britain: an appraisal of casual factors and conservation actions. Ibis 130: 519-600.

Potts, G.R. 2012. Partridges: Countryside Barometer. Collins.

R Core Development Team. 2014. R version 3.0.2: A Language and Environment for Statistical Computing. Austria: R Foundation for Statistical Computing.

Ramsay, S.L. \& Houston, D.C. 2003. Amino acid composition of some woodland arthropods and its implications for breeding tits and other passerines. Ibis 145: 227-232.

Southwood, T. \& Cross, D. 2002. Food requirements of grey partridge Perdix perdix chicks. Wildl. Biol 8: 175-183.

Stoate, C., Boatman, N.., Borralho, R.., Carvalho, C.R., Snoo, G.R.D. \& Eden, P. 2001. Ecological impacts of arable intensification in Europe. J. Environ. Manage 63: 337-365.

Stoate C., Henderson, I.G., Parish, D.M.B. 2004. Development of an agr-environment scheme option: seed-bearing crops for farmland birds. Ibis 146: 203-209

Summers-Smith, J.D. 1995. The Tree Sparrow. J.D. Summers-Smith, Guisborough.

Tremblay, A. 2015. Package "LMERConvienceFunctions". URL http://cran.rproject.org/web/packages/LMERConvenienceFunctions/LMERConvenienceFunctions.pdf

Vickery, J.A., Carter, N. \& Fuller, R.J. 2002. The potential value of managed cereal field margins as foraging habitats for farmland birds in the UK. Agric. Ecosyst. Environ 89: 41-52.

Wright, J., Both, C., Cotton, P.A \& Bryant, D. 1998. Quality vs. quantity: energitic and nutritional trade-offs in parental provisioningstrategies. J.Anim. Ecol 67: 620-634. 


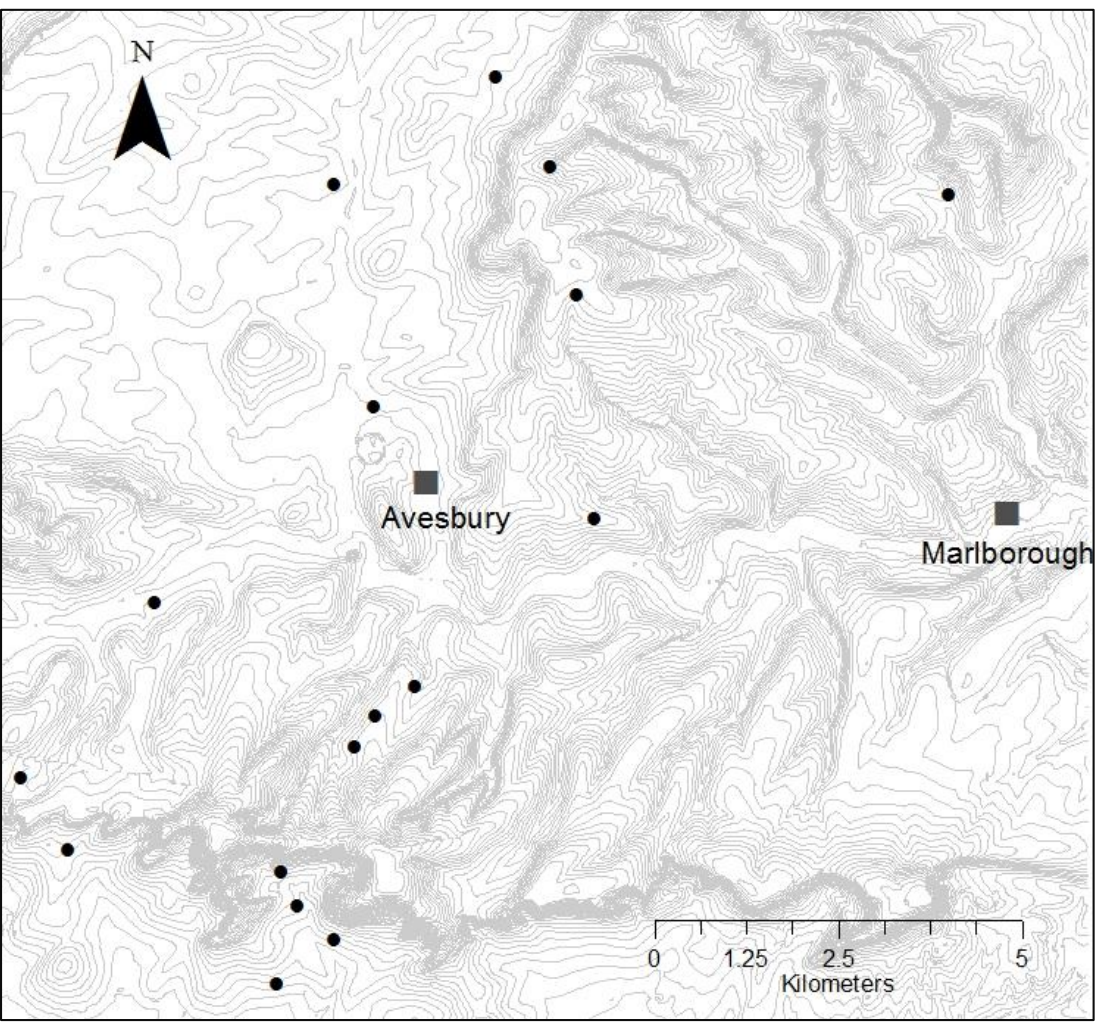

249 Figure 1. Map of the study area, Tree Sparrow colonies are marked as black circles. 250 Groups of nest boxes that were separated by more than $400 \mathrm{~m}$ were defined as colonies. 
Table 1. Results of GLMMs for the effect of Grass ES and WBS on Tree sparrow nestling diet. Models were run using binomial error distributions. Each dietary group was modelled separately. The estimated slope ( \pm SE), Wald test statistic (z-value) and pvalue significance are given. Grass ES and WBS habitat coverage was arcsine square root transformed to normalise their distribution.

\begin{tabular}{|c|c|c|c|c|}
\hline Response & Explanatory & Estimate \pm SE & z-value & $\mathbf{p}$ \\
\hline \multirow[t]{3}{*}{ Araneae } & Intercept & $1.26 \pm 0.72$ & 1.74 & 0.082 \\
\hline & Grass ES & $-3.80 \pm 3.13$ & -1.21 & 0.225 \\
\hline & WBS & $5.61 \pm 3.56$ & 1.57 & 0.116 \\
\hline \multirow[t]{3}{*}{ Carabidae } & Intercept & $1.93 \pm 0.71$ & 2.71 & $<0.01$ \\
\hline & Grass ES & $-0.58 \pm 3.12$ & -0.19 & 0.851 \\
\hline & WBS & $-2.10 \pm 3.14$ & -0.67 & 0.502 \\
\hline \multirow{3}{*}{$\begin{array}{l}\text { Other Coleoptera } \\
\text { adults }\end{array}$} & Intercept & $1.12 \pm 1.40$ & 0.80 & 0.425 \\
\hline & Grass ES & $3.01 \pm 4.67$ & 0.65 & 0.519 \\
\hline & WBS & $-1.69 \pm 8.12$ & -0.21 & 0.835 \\
\hline \multirow[t]{3}{*}{ Coleoptera larvae } & Intercept & $-1.35 \pm 1.42$ & -0.95 & 0.342 \\
\hline & Grass ES & $3.36 \pm 5.37$ & 0.63 & 0.532 \\
\hline & WBS & $2.13 \pm 5.79$ & 0.37 & 0.713 \\
\hline \multirow[t]{3}{*}{ Diptera } & Intercept & $3.24 \pm 0.97$ & 3.35 & $<0.001$ \\
\hline & Grass ES & $-2.36 \pm 3.79$ & -0.62 & 0.534 \\
\hline & WBS & $-3.76 \pm 4.00$ & -0.94 & 0.348 \\
\hline \multirow[t]{3}{*}{ Lepidoptera larvae } & Intercept & $-1.06 \pm 1.18$ & -0.94 & 0.349 \\
\hline & Grass ES & $0.53 \pm 4.47$ & 0.12 & 0.906 \\
\hline & WBS & $-0.39 \pm 5.18$ & -0.08 & 0.940 \\
\hline \multirow[t]{3}{*}{ Tipulidae } & Intercept & $2.18 \pm 1.40$ & 1.56 & 0.119 \\
\hline & Grass ES & $-5.66 \pm 4.70$ & -1.20 & 0.229 \\
\hline & WBS & $-4.18 \pm 5.86$ & -0.71 & 0.475 \\
\hline \multirow[t]{3}{*}{ Seed } & Intercept & $-0.59 \pm 1.01$ & -0.59 & 0.557 \\
\hline & Grass ES & $1.66 \pm 4.41$ & 0.38 & 0.707 \\
\hline & WBS & $12.80 \pm 5.67$ & 2.26 & $<0.05$ \\
\hline
\end{tabular}

